\title{
The Effect Of Open Ended Learning (OEL) Model Towards Students' Reading Comprehension Skill At SMAN 1 Keruak
}

\author{
${ }^{1}$ DiansyahNaqsabandi, ${ }^{2}$ Muliani \\ English Language Education,Faculty of Culture, Management and Business, Mandalika University of \\ Education \\ English Language Education, Faculty of Culture, Management and Business \\ Mandalika University of Education \\ Email: diansyahnaqsabandi02@gmail.com, muliani@ikipmataram.ac.id
}

\begin{abstract}
This research is aimed at finding out the effect of Open Ended Learning (OEL) Model toward Students' Reading Comprehension Skill at SMAN 1 Keruak. The research is Quantitative Experimental Research. The design is used quasi experimental with non-equivalent. The population of the study was the first grade students of SMAN 1 Keruak consists of nine classes. Two classes were chosen as the sample, those were IPS I as the experimental group consisting of 25 students and IPS IV as the control group consisting of 25 students. They were chosen by using cluster sampling technique. Experimental group was treated by Open Ended Learning (OEL) Model and control group was treated by Direct Instruction (DI) Model. The instrument that used was reading test in form of multiple choices consisting of 30 items. Then the score were analyzed by using SPSS_26. It shows that the mean score of experimental group is $\mathbf{5 2 . 6 4}$ the maximum score is $\mathbf{7 6}$, the minimum score is 33 , and the standard deviation is 11.636. While the maximum score of control group is 70, the minimum score is 37 , the mean score is 49.08, and the standard deviation is 11.683. The value of sig. (2-tailed) is 0.006 where the value of sig. (2-tailed) is lower than the significance level (0.05). Therefore based on the result of the statistical analysis, it can be concluded that there is positive effect of Open Ended Learning (OEL) Model towards students' reading comprehension skill at the first grade students of SMAN 1 Keruak. In other words, alternative hypothesis (Ha) is accepted and null hypothesis (Ho) is rejected.
\end{abstract}

Key word:Open Ended Learning (OEL) Model, Reading Comprehension.

Abstrak. Penelitian ini bertujuan untuk mengetahui pengaruh model pembelajaran Open-Ended (OE) terhadap keterampilan pemahaman membaca siswa di SMAN 1 Keruak. Penelitian ini merupakan penelitian eksperimental kuantitatif. Desain yang digunakan adalah quasi eksperimental dengan nonekuivalen. Populasi penelitian adalah siswa kelas I SMAN 1 Keruak yang terdiri dari Sembilan kelas. Dua kelas dipilih sebagai sampel yaitu IPS I sebagai kelompok eksperimen yang terdiri dari 25 siswadan IPS IV sebagai kelompok kontrol yang terdiri dari 25 siswa. Mereka dipilih menggunakan teknik cluster random sampling. Kelompok eksperimen diberi perlakuan model pembelajaran OpenEnded (OE) dan kelompok control diberi model pembelajaran Direct-Instruction (DI). Instrument yang digunakan adalah test membaca berupa pilihan ganda yang terdiri dari 30 butir soal. Kemudian skor tersebut dianalisis menggunakan SPSS_26. Hasilnya menunjukkan nilai rata-rata kelompok eksperimen adalah 52.64, nilai maksimum 33, dan standard deviasi 11.636. Sedangkan nilai maksimum kelompok control adalah 70, nilai minimum 37, nilai rata-rata 49.08, dan standard deviasi 11.683. Nilai sig. (2tailed) adalah 0.006 dimana nilai sig. (2-tailed) lebih rendah dari tingkat signifikansi (0.050. Oleh karena itu berdasarkan hasil analisis statistic dapat disimpulkan bahwa terdapat pengaruhpositif model pembelajaran Open-Ended (OE) terhadap keterampilan pemahaman membaca siswa pada siswa tingkat pertama di SMAN 1 Keruak. Dengan kata lain, hipotesis alternative (Ha) diterima dan hipotesis nol (Ho) di tolak. 
Kata kunci: Model Pembelajaran Open-Ended (OE), KeterampilanPemahamanMembaca.

\section{INTRODUCTION}

Reading comprehension is the ability of the readers to get the information from the text. According to Snow (2002: 11) reading comprehension is defined as the process of simultaneously extracting and constructing meaning through interaction and involvement with written language. Meanwhile, without a comprehension skill in reading, whole efforts to portray the printed text would be meaningless and it will be difficult to get the information instead.

Based on the explanation above, in order to ease the students able to draw the conclusion from the printed text strategically and obtain the learning success especially in reading; they need such skill which is very important, and that skill is reading comprehension skill. In contrast, reading comprehension skill is highly fundamental for the students in order to obtain a good learning result in reading.

However, based on the pre-observation that researcher conducted. The researcher found that there were many learners who still had low reading comprehension skills. It was proven when the researcher observed a learning process at the first grade students of SMAN 1 Keruak.

In that case, the students had difficulties in comprehending the information of the text presented in the textbooks that deal with. Moreover, in learning reading the students had to comprehend the text that dallying their time a

\section{RESEARCH METHOD}

This research is quasi-experimental in form of non-equivalent (pre-test, post-test) control group design to obtain the main aim of this research.According to Creswell (2014: 172) in this design, a popular approach to quasiexperiments, the experimental group $\mathrm{A}$ and the control group B are selected without random assignment. Both groups take a pre-test and post-test. The design can be represented as:

\section{Table 1.Scheme of the Research}

lot. And most of them tend to get bored during teaching and learning activity and the looked passive in the classroom. In contrast, the students were not success in learning reading.

Concerning those learning situations, it was caused by the teacher strategy that used was not appropriate to be implemented to the students in reading. The teacher used direct instruction (DI) model in teaching reading; meanwhile by using this teaching model was merely proposed the students to achieve learning goal without considering the multilevel of student's ability. Thus, teaching and learning activity tend to be dominated by the teacher only and the students looked passive in the classroom.

Regarding with those problems, it was important to decide the most appropriate teaching strategy in order to ease the students to be more active and capable of comprehending reading material. According to Brown (2004:7) stated that teaching reading comprehension may be defined as a process of showing or helping the students or someone to learn how to do something, giving instruction, guiding in the study of something, providing knowledge, and causing to know or understand.

Therefore, the researcher put an interest to conduct an experimental research to investigate whether by implementing Open Ended Learning (OEL) learning model would affected students' reading comprehension skill at the first grade students of SMAN 1 Keruak.

\begin{tabular}{|c|c|c|}
\hline O1 & $\mathrm{X}$ & $\mathrm{O} 2$ \\
\hline O3 & - & $\mathrm{O} 4$ \\
\hline
\end{tabular}

Where:

O1 : Pre-test for experimental group

$\mathrm{O} 2$ : Post-test for experimental group

O3 : Pre-test for control group

$\mathrm{O} 4$ : Post-test for control group

X : Open Ended Learning Model

- : Direct Instruction (DI) Model

The population of this research was the entire first grade students of SMAN 1 Keruak and the total of them were 214 students that 
distributed into nine classes namely X MIPA I, $X$ MIPA II, X MIPA III, X MIPA IV, X MIPA $\mathrm{V}, \mathrm{X}$ IPS I, $\mathrm{X}$ IPS II, $\mathrm{X}$ IPS III, and $\mathrm{X}$ IPS IV.The sample was selected by using cluster random sampling technique. As the result, IPS I as experimental group consist of 25 students and IPS IV as control group consist of 25 students.

In this research, the instrument that used was reading test in form of multiple choice consist of 30 items deal with seven indicators of reading. To collect the data the researcher administered pre-test and post-test to experimental and control groups. In this process of collecting data, the researcher gave the pretest to the students in order to know the prior students' ability before having a treatment. The result of the test became the evaluation before using Open Ended Learning (OEL) model as the treatment of this research. And post-test was intended to identify the student's comprehension after administering the treatment. In the process of offering pre-test and post-test, the researcher converted the test into google form in order to ease the students in taking the test online. The result of the scoring then was compared with pre-test score. The pretest and post-test had been used in the same aspects and same questions.

After collecting the data, the researcher used quantitative data by using statistical program SPSS_26 to analysethe descriptive analysis such as: mean, mode, median, and standard deviation. And inferential statistic was used to obtain normality and homogeneity of the population from which sample was taken. To obtain the final result of this study and answer the research hypothesis the researcher used independent sample T-test with significance level 95\% (0.05).

\section{FINDINGS AND DISCUSSION}

\section{Descriptive Statistic}

The result of descriptive statistic is preserved on SPSS_26 below:
Table
2.Result of
Descriptive

\begin{tabular}{|c|c|c|c|c|c|}
\hline \multicolumn{6}{|c|}{ Statistics } \\
\hline & & $\begin{array}{c}\text { Pre-test } \\
\text { Experimental }\end{array}$ & $\begin{array}{c}\text { Post-test } \\
\text { Experimental }\end{array}$ & $\begin{array}{l}\text { Pre-test } \\
\text { Control }\end{array}$ & $\begin{array}{l}\text { Post-test } \\
\text { Control }\end{array}$ \\
\hline \multirow[t]{2}{*}{$\mathrm{N}$} & Valid & 25 & 25 & 25 & 25 \\
\hline & Missing & 0 & 0 & 0 & 0 \\
\hline \multicolumn{2}{|c|}{ Mean } & 43.60 & 52.64 & 44.48 & 49.08 \\
\hline \multicolumn{2}{|c|}{ Median } & 43.00 & 50.00 & 40.00 & 46.00 \\
\hline \multicolumn{2}{|c|}{ Mode } & 36 & 43 & 40 & 46 \\
\hline \multicolumn{2}{|c|}{ Std. Deviation } & 10.492 & 11.636 & 11.797 & 11.683 \\
\hline \multicolumn{2}{|c|}{ Range } & 36 & 43 & 36 & 37 \\
\hline \multicolumn{2}{|c|}{ Minimum } & 30 & 33 & 30 & 33 \\
\hline \multicolumn{2}{|c|}{ Maximum } & 66 & 76 & 66 & 70 \\
\hline \multicolumn{2}{|r|}{ Sum } & 1090 & 1316 & 1112 & 1227 \\
\hline
\end{tabular}

The result of pre-test control class showed that $\mathrm{N}$ was 25 students. After computing the data by using SPSS_26 software, the researcher found the maximum score was 66 , the minimum score was 30 , the mean score was 44.48 , the median score was 40.00 , the mode score was 40 and the standard deviation was 11.797.

Table 3.Pre-test Control Cla

\begin{tabular}{|c|c|c|c|c|c|}
\hline \multicolumn{6}{|c|}{ Pre-test Control } \\
\hline & & $\begin{array}{c}\text { Freque } \\
\text { ncy }\end{array}$ & Percent & $\begin{array}{c}\text { Valid } \\
\text { Perce } \\
\text { nt }\end{array}$ & $\begin{array}{c}\text { Cumul } \\
\text { ative } \\
\text { Percen } \\
t\end{array}$ \\
\hline \multirow{12}{*}{$\begin{array}{l}\text { Vali } \\
\text { d }\end{array}$} & 30 & 3 & 12.0 & 12.0 & 12.0 \\
\hline & 33 & 3 & 12.0 & 12.0 & 24.0 \\
\hline & 36 & 3 & 12.0 & 12.0 & 36.0 \\
\hline & 40 & 4 & 16.0 & 16.0 & 52.0 \\
\hline & 43 & 2 & 8.0 & 8.0 & 60.0 \\
\hline & 46 & 2 & 8.0 & 8.0 & 68.0 \\
\hline & 53 & 2 & 8.0 & 8.0 & 76.0 \\
\hline & 56 & 1 & 4.0 & 4.0 & 80.0 \\
\hline & 60 & 1 & 4.0 & 4.0 & 84.0 \\
\hline & 63 & 3 & 12.0 & 12.0 & 96.0 \\
\hline & 66 & 1 & 4.0 & 4.0 & 100.0 \\
\hline & $\begin{array}{l}\text { Tot } \\
\text { al }\end{array}$ & 25 & 100.0 & 100.0 & \\
\hline
\end{tabular}

ss Frequency of Distribution

Figure 1.Histogram Pre-test of Control Class

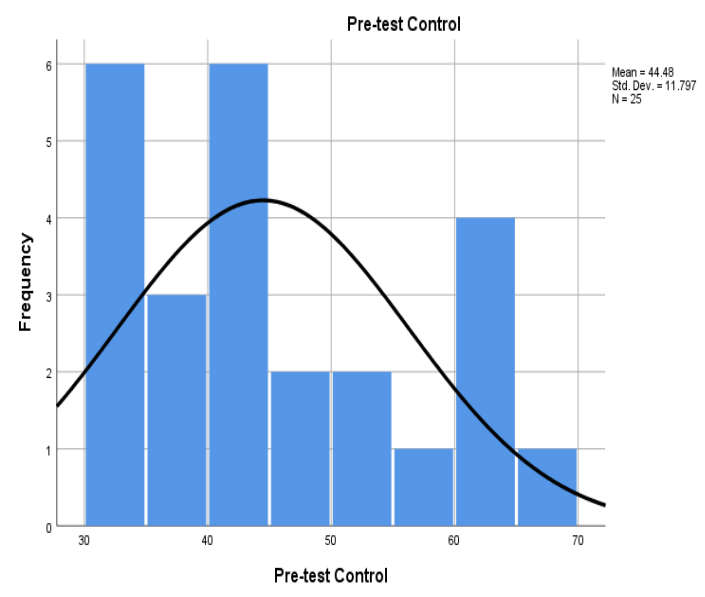


Jurnal Ilmiah Mandala Education

http://ejournal.mandalanursa.org/index.php/JIME/index

terakreditasi Peringkat 4 (No. SK: 36/E/KPT/2019)

While, the result of post-test control class showed that $\mathrm{N}$ was 25 students. After computing the data by using SPSS_26 software, the researcher found the maximum score was 70 , the minimum score was 37 , the mean score was 49.08 , the median score was 46.00 , the mode score was 46 and the standard deviation was11.683.

Table 4.Post-test Control Class Frequency of Distribution

\begin{tabular}{|c|c|c|c|c|c|}
\hline \multicolumn{6}{|c|}{ Post-test Control } \\
\hline & & $\begin{array}{l}\text { Frequ } \\
\text { ency }\end{array}$ & $\begin{array}{c}\text { Perce } \\
\text { nt }\end{array}$ & $\begin{array}{c}\text { Valid } \\
\text { Percent }\end{array}$ & $\begin{array}{c}\text { Cum } \\
\text { ulativ } \\
\text { e } \\
\text { Perc } \\
\text { ent }\end{array}$ \\
\hline \multirow{11}{*}{$\begin{array}{l}\text { Vali } \\
\text { d }\end{array}$} & 33 & 3 & 12.0 & 12.0 & 12.0 \\
\hline & 36 & 2 & 8.0 & 8.0 & 20.0 \\
\hline & 40 & 2 & 8.0 & 8.0 & 28.0 \\
\hline & 43 & 2 & 8.0 & 8.0 & 36.0 \\
\hline & 46 & 5 & 20.0 & 20.0 & 56.0 \\
\hline & 50 & 3 & 12.0 & 12.0 & 68.0 \\
\hline & 56 & 1 & 4.0 & 4.0 & 72.0 \\
\hline & 60 & 2 & 8.0 & 8.0 & 80.0 \\
\hline & 66 & 4 & 16.0 & 16.0 & 96.0 \\
\hline & 70 & 1 & 4.0 & 4.0 & 100.0 \\
\hline & Total & 25 & 100.0 & 100.0 & \\
\hline
\end{tabular}

Figure 2.Histogram Post-test of Control Class

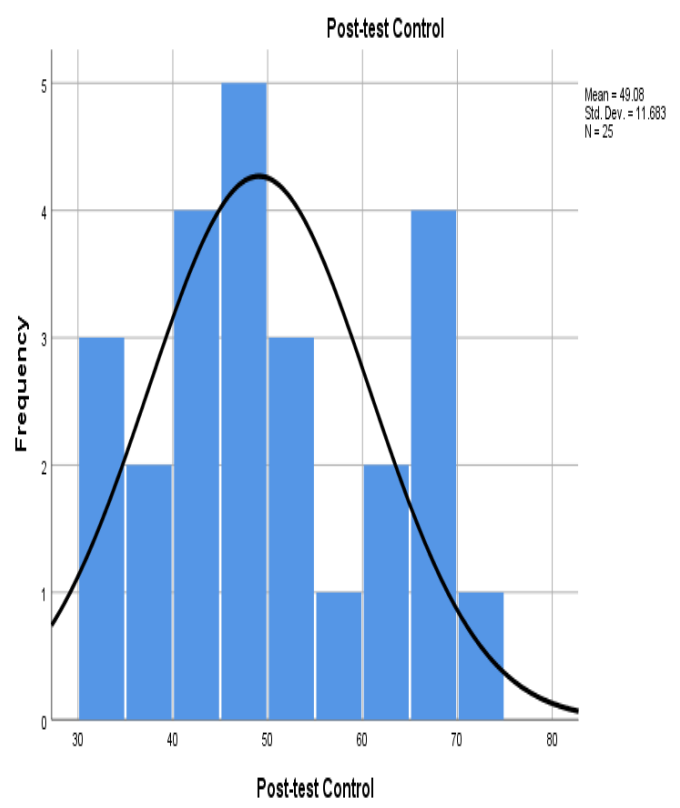

The result of pre-test of experimental class showed that $\mathrm{N}$ was 25 students. After computing the data by using SPSS_26 software,
Vol. 6. No. 1. April 2020

p-ISSN: 2442-9511 e-ISSN: 2656-5862

the researcher found the maximum score was 66 , the minimum score was 30 , the mean score was 43.60 , the median score was 43.00 , the mode score was 36 and the standard deviation was 10.492 .

Table 5.Pre-test Experimental Class Frequency of Distribution

\begin{tabular}{|c|c|c|c|c|c|}
\hline \multicolumn{6}{|c|}{ Post-test Experimental } \\
\hline & & $\begin{array}{c}\text { Freque } \\
\text { ncy }\end{array}$ & $\begin{array}{l}\text { Perc } \\
\text { ent }\end{array}$ & $\begin{array}{l}\text { Valid } \\
\text { Percent }\end{array}$ & $\begin{array}{l}\text { Cumulati } \\
\text { ve } \\
\text { Percent }\end{array}$ \\
\hline \multirow{13}{*}{$\begin{array}{l}\text { Vali } \\
d\end{array}$} & 33 & 1 & 4.0 & 4.0 & 4.0 \\
\hline & 40 & 3 & 12.0 & 12.0 & 16.0 \\
\hline & 43 & 4 & 16.0 & 16.0 & 32.0 \\
\hline & 46 & 3 & 12.0 & 12.0 & 44.0 \\
\hline & 50 & 2 & 8.0 & 8.0 & 52.0 \\
\hline & 53 & 2 & 8.0 & 8.0 & 60.0 \\
\hline & 56 & 2 & 8.0 & 8.0 & 68.0 \\
\hline & 60 & 2 & 8.0 & 8.0 & 76.0 \\
\hline & 63 & 1 & 4.0 & 4.0 & 80.0 \\
\hline & 66 & 1 & 4.0 & 4.0 & 84.0 \\
\hline & 70 & 3 & 12.0 & 12.0 & 96.0 \\
\hline & 76 & 1 & 4.0 & 4.0 & 100.0 \\
\hline & Total & 25 & 100.0 & 100.0 & \\
\hline
\end{tabular}

Figure 3.Histogram Pre-test of Experimental

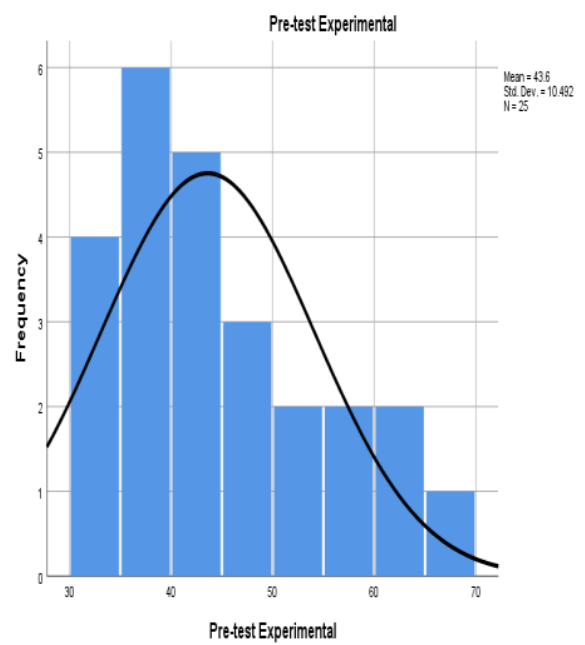

While, the result of post-test experimental class showed that $\mathrm{N}$ was25 students. After computing the data by using SPSS_26 software, the researcher found the maximum score was 76 , the minimum score was 33 , the mean score was 52.64, the median score was 50.00, the mode score was 43 and the standard deviation was11.636. 
Jurnal Ilmiah Mandala Education

http://ejournal.mandalanursa.org/index.php/JIME/index

terakreditasi Peringkat 4 (No. SK: 36/E/KPT/2019)

Table 6.Post-test Experimental Class

Frequency of Distribution

\begin{tabular}{|c|c|c|c|c|c|}
\hline \multicolumn{6}{|c|}{ Pre-test Experimental } \\
\hline & & $\begin{array}{c}\text { Freque } \\
\text { ncy }\end{array}$ & $\begin{array}{c}\text { Percen } \\
t\end{array}$ & $\begin{array}{c}\text { Valid } \\
\text { Percen } \\
t\end{array}$ & $\begin{array}{c}\text { Cumul } \\
\text { ative } \\
\text { Percen } \\
t\end{array}$ \\
\hline \multirow[t]{13}{*}{ Valid } & 30 & 3 & 12.0 & 12.0 & 12.0 \\
\hline & 33 & 1 & 4.0 & 4.0 & 16.0 \\
\hline & 36 & 6 & 24.0 & 24.0 & 40.0 \\
\hline & 40 & 2 & 8.0 & 8.0 & 48.0 \\
\hline & 43 & 3 & 12.0 & 12.0 & 60.0 \\
\hline & 46 & 3 & 12.0 & 12.0 & 72.0 \\
\hline & 50 & 1 & 4.0 & 4.0 & 76.0 \\
\hline & 53 & 1 & 4.0 & 4.0 & 80.0 \\
\hline & 56 & 2 & 8.0 & 8.0 & 88.0 \\
\hline & 60 & 1 & 4.0 & 4.0 & 92.0 \\
\hline & 63 & 1 & 4.0 & 4.0 & 96.0 \\
\hline & 66 & 1 & 4.0 & 4.0 & 100.0 \\
\hline & $\begin{array}{l}\text { Tot } \\
\text { al }\end{array}$ & 25 & 100.0 & 100.0 & \\
\hline
\end{tabular}

Figure 4.Histogram Post-test of Experimental

\begin{tabular}{|c|c|c|c|c|c|}
\hline \multicolumn{6}{|c|}{ Test of Homogeneity of Variances } \\
\hline & & $\begin{array}{l}\text { Levene } \\
\text { Statistic }\end{array}$ & df1 & df2 & Sig \\
\hline \multirow[t]{4}{*}{$\begin{array}{l}\text { Scor } \\
\text { e }\end{array}$} & $\begin{array}{l}\text { Based on } \\
\text { Mean }\end{array}$ & .283 & 3 & 96 & $\begin{array}{r}.83 \\
7 \\
\end{array}$ \\
\hline & $\begin{array}{l}\text { Based on } \\
\text { Median }\end{array}$ & .156 & 3 & 96 & $\begin{array}{r}.92 \\
6\end{array}$ \\
\hline & $\begin{array}{l}\text { Based on } \\
\text { Median } \\
\text { and with } \\
\text { adjusted df }\end{array}$ & .156 & 3 & $\begin{array}{r}92 . \\
13 \\
9\end{array}$ & $\begin{array}{r}.92 \\
6\end{array}$ \\
\hline & $\begin{array}{l}\text { Based on } \\
\text { trimmed } \\
\text { mean }\end{array}$ & .295 & 3 & 96 & $\begin{array}{r}.82 \\
9\end{array}$ \\
\hline
\end{tabular}

Post.test Experimental

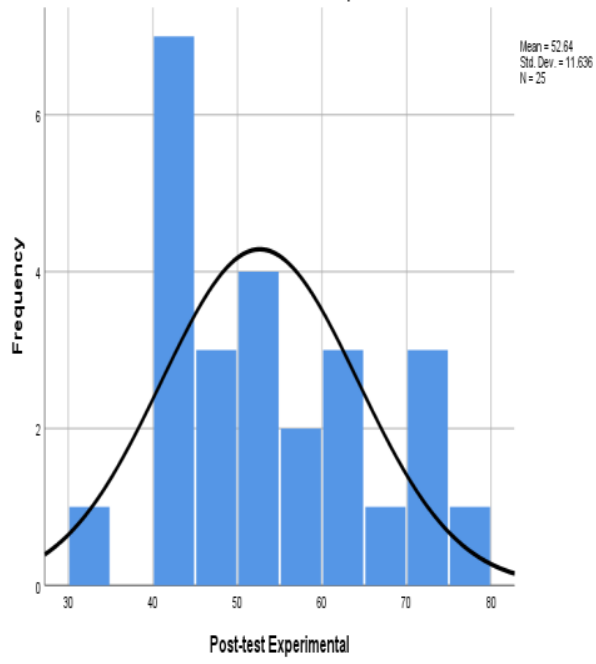

Vol. 6. No. 1. April 2020

p-ISSN: 2442-9511 e-ISSN: 2656-5862

\section{Inferential Statistics}

Before the data were analysed with $\mathrm{T}$ test, the researcher needs to administer the normality and homogeneity test of samples. The normality analysis in this study was Shapiro-Wilk and the homogeneity analysis was Levene' test. The result of normality and homogeneity test is preserved on SPSS_26 below:

\begin{tabular}{|c|c|c|c|c|c|c|c|}
\hline & ble & 7. & est & of & & Tor & nalit \\
\hline & & Tests & No & nalit & & & \\
\hline & & Kolmogi & $p v-s i$ & irnova & Sha & iro- & Vilk \\
\hline & & Statisti & $d f$ & & $\begin{array}{l}\text { Stati } \\
\text { stic }\end{array}$ & Df & \\
\hline $\begin{array}{l}\text { Sc } \\
\text { ore }\end{array}$ & $\begin{array}{l}\text { Pre-test } \\
\text { Experim } \\
\text { ental }\end{array}$ & .166 & 25 & .075 & .927 & 25 & $\begin{array}{r}07 \\
3\end{array}$ \\
\hline & $\begin{array}{l}\text { Post-test } \\
\text { Experim } \\
\text { ental }\end{array}$ & .156 & 25 & .119 & .946 & 25 & .20 \\
\hline & $\begin{array}{l}\text { Pre-test } \\
\text { Control }\end{array}$ & .168 & 25 & .067 & .900 & 25 & $\begin{array}{r}.01 \\
8\end{array}$ \\
\hline & $\begin{array}{l}\text { Post-test } \\
\text { Control }\end{array}$ & .164 & 25 & .081 & .921 & 25 & $\begin{array}{r}.05 \\
4\end{array}$ \\
\hline
\end{tabular}

From the output of SPSS_26, it was known that the significance value of pre-test experimental was 0.073 , and Sig-value of posttest experimental was 0.200 , Sig-value of pretest control was 0.018 , Sig -value of post-test control was 0.054 . So, it could be interpreted whole the data were in normal distribution because those all were bigger than significance level $(a=0,05)$.

Based on the SPSS_26 softwareoutput table, Homogeneity of Variance test in the Sig. columnwas 0.829 . The test is called homogeny if the significant score more than 0.05 , where this data displayed that significant score was $0.829>0.05$,it means that the data was homogeneousTable 8. Test of Homogeneityof Variance

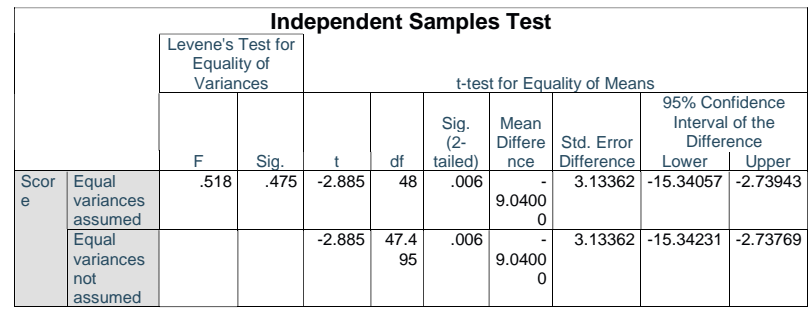

\section{IndependentSampleTest}

After knowing the result of descriptive statistics, normality test, and homogeneity test.The researcher wanted to know the significant difference ofstudents' reading comprehension skill before and after had been 
taught by using Open Ended Learning (OEL) model. To obtain the final result and to answer the hypothesis of this study, the researcher used Independent Sample Test through SPSS_26. And the result displayed by table below.

Based on the result showed above, the value of sig. (2-tailed) is lower than the significance level, whereSig (2 tailed) $0.006<$ (0.05). It could be concluded, if the results of sig 2-tailed lower than 0.05, it means Alternative hypothesis (Ha) is accepted, and Open Ended Learning (OEL) Model had significant effect towards students' reading comprehension skill at the first grade students of SMAN 1 Keruak in academic year 2019/2020.

\section{DISCUSSION}

In this study, there was only one statement of the problem proposed as"was Open Ended Learning (OEL) model had effectiveness towards students' reading comprehension at the first grade students of SMAN 1 Keruak. This statement of the problem had been answered based on the result of research finding. As the result, the value of Sig (2-tailed) was 0.006 lower than significance level 0.05 . So, it could be concluded thatOpen Ended Learning (OEL) modelhadsignificant effect towards students' reading comprehension skill.

In contrast, the use of Open Ended Learning (OEL) Model towards students' reading comprehension skill at SMAN 1 Keruak brought the advantagesto the students in developing their ability and skill in reading comprehension. In this case, by using Open Ended Learning (OEL) Model had the following advantages: a) students able to Expanding students' creativity especially in expressing their ideas and thought freely; b) Cultivating students' cooperative; c) Growing students' skill especially in finding a particular information from the text strategically; d) The students gave more attention and selfconfidence in learning independently and cooperatively as well; e) Train the students to analyse the problem and taking the conclusion cooperatively; f) Made the students to be more active in teaching and learning process.

In addition, by using this learning model the students were able to develop their reading comprehension skill that deal with seven indicators of reading, one of them is finding main idea; students who taught by using Open Ended Learning (OEL) model were able to discuss the understanding of main idea and how to find it cooperatively, so they can teach each other during discussion. The second one is vocabulary; students were able to share experience and knowledge about some difficult vocabularies on the passage. The third one is finding fact and detail information; students able to seek for the information that they need from the text by using many ways in order to arrive to the answer. The forth one is exception; students able to analyse the information that do not mentioned on the text it was caused by using Open Ended Learning (OEL) model the researcher gave them an openness to think and analyse the passage freely and cooperatively. The fifth one is location of information; the students were trained to think creatively to obtain specific information from the text. The sixth one is inference; students who taught by Open Ended learning had ability in drawing conclusion from the text, and the last one is reference; students was trained to be able in referring a particular text during teaching and learning activity.

On the other side, the students were able to improve their skill in reading comprehension due to the main point of Open Ended Learning (OEL) derives the students to cooperate with others to achieve a common goal produces higher achievement and greater productivity than working alone.

Thus, those advantages had been brought about by the process of Open Ended Learning (OEL) model that gave the students openness to think and discuss their ideas freely in order to achieve the most possible answers. So, the students seemed to be active and strategic during teaching and learning activity especially 
in developing their skill in reading comprehension.

\section{CONCLUSION}

Reading comprehension skill is highly fundamental for the students in order to obtain a good learning result in reading. So, in order to ease the students to be able to comprehend the reading passage comprehensively and strategically, the teacher needs to constitute the students to learn how to do something, giving instruction, guiding in the study of something, providing knowledge, and causing to know or understand.

Hence, by using Open Ended Learning (OEL) model in this research was able to stimulate the students' ability or skill in understanding the texts comprehensively. This statement was proven based on the findings and discussion of the research. And finally, the researcher came into the conclusions which by using Open Ended Learning (OEL) model had significance effect towards students' reading comprehension at SMAN 1 Keruak in academic year 2019/2020.

\section{SUGGESTION}

Related to the conclusion above, the researcher would like to offer some suggestion to the teacher, students, and the next researcher.

1. For the Teacher

The teacher should be more aware of determining the most appropriate learning model in teaching reading, so that the students able to develop their own ability or skill in finding particular information individually or cooperatively in reading, Instead of driving them into tight teaching and learning process that caused the students tend to get bored during teaching and learning activity.

2. For the Students

The students are attempted to engage in teaching and learning activity in order to make a learning atmosphere become active so that the students do not need to receive the information from the teacher only. But, they are able to gain the knowledge by themselves.

\section{For the Next Researcher}

The researcher expects forthe other researchers could use this study as one of the references in conducting similar study. If the next researcher wants to use this technique, the researcher has to make a good planning in advance.

\section{REFFERENCES}

Alison L. Bailey \& Margaret Heritage. 2008. Formative assessment for literacy, grades K6. Building reading and academic language skills across thecurriculum, Corwin press.

Brown, H. Douglas. 2004. Language assesment: Principles and Classroom Practice. United States of America.

Chesla, Elizabeth L. 2002. Test of English as a Foreign Language, Exam successes in only 6 steps,Learning Express, First Edition. New York.

Creswell, Jhon W. 2014. Research design:qualitative, quantitative, and mixed methods approaches. United States of America.

Cohen, Louis. et.al., 2007. Research Methods in Education, Sixth Edition. Published in the USA and Canadaby Routledge

Hannafin, Land, \& Oliver 2001.Developing and Refining Mental Models inOpen-Ended

Learning Environments: A Case Study. Educational Tech-nology Research and Development, 49(4), 5-32 ISSN 10421629

Jhonson, Andrew P. 2008. Teaching Reading and Writing: a guidebook for tutoring and remendiating students. United State of America publishing, New York.

Kothari, C. R. 2004. ResearchMethodology, Methods \& Techniques. Former Principal, Colege of Commerece University of Rajasthan, Japur (India)

Miler, Stave. 2005. Experimental design and Statistics. Taylor \& Frances e-Library. 
Neuman, Lawrence W. 2014. Social Research Methods: Qualitative and Quantitative Approaches.British Library Cataloguing-in-Publication. Printed in the United States of America

Riadi, Muchlisin. 2019. ModelPembelajaran Open Ended Learning. (Retrived from http://www.kajianpustaka.com/2019/03/ model-pembelajaran-open-endedlearning.html.Accessed on $05^{\text {th }}$ march, 2019. 03.55. PM)

Sholikhah, Ziyadatush. 2017. Effektifitas Model Pembelajaran Open-Ended terhadapPrestasiBelajarMatematikaDiti njaudariKreativitasSiswa. Tegal: UniversitasPanca Sakti. JES-MAT, Vol. 4No.1

Snow, Catherine E. 2002. Reading for understanding: toward a research and development program in reading comprehension. Published in the United States of America by RAND, Santa Monica.

Witoko, R, Wardono.2019. Analisis Model Pembelajaran Open-Ended Learning (OEL) dengan Assessment for Learning (AFL) ditinjaudariKreativitasBelajarMatemati ka. PRISMA, Prosiding Seminar NasionalMatematika.Vol 2,748-753 